\title{
Remotely monitoring ecosystem respiration from various grasslands along a large-scale east-west transect across northern China
}

\author{
Xuguang Tang ${ }^{1,2}$, Yanlian Zhou ${ }^{3}$, Hengpeng Li ${ }^{4}$, Li Yao ${ }^{1}$, Zhi Ding ${ }^{1}$, Mingguo Ma ${ }^{1,2}$ and Pujia Yu ${ }^{1,2^{*}}$
}

\begin{abstract}
Background: Grassland ecosystems play an important role in the terrestrial carbon cycles through carbon emission by ecosystem respiration $\left(R_{e}\right)$ and carbon uptake by plant photosynthesis (GPP). Surprisingly, given $R_{e}$ occupies a large component of annual carbon balance, rather less attention has been paid to developing the estimates of $R_{e}$ compared to GPP.

Results: Based on 11 flux sites over the diverse grassland ecosystems in northern China, this study examined the amounts of carbon released by $R_{e}$ as well as the dominant environmental controls across temperate meadow steppe, typical steppe, desert steppe and alpine meadow, respectively. Multi-year mean $R_{e}$ revealed relatively less $\mathrm{CO}_{2}$ emitted by the desert steppe in comparison with other grassland ecosystems. Meanwhile, $C$ emissions of all grasslands were mainly controlled by the growing period. Correlation analysis revealed that apart from air and soil temperature, soil water content exerted a strong effect on the variability in $R_{e}$, which implied the great potential to derive $R_{e}$ using relevant remote sensing data. Then, these field-measured $R_{e}$ data were up-scaled to large areas using time-series MODIS information and remote sensing-based piecewise regression models. These semi-empirical models appeared to work well with a small margin of error ( $R^{2}$ and RMSE ranged from 0.45 to 0.88 and from 0.21 to $0.69 \mathrm{~g} \mathrm{C} \mathrm{m}^{-2} \mathrm{~d}^{-1}$, respectively).
\end{abstract}

Conclusions: Generally, the piecewise models from the growth period and dormant season performed better than model developed directly from the entire year. Moreover, the biases between annual mean $R_{e}$ observations and the remotely-derived products were usually within $20 \%$. Finally, the regional $R_{e}$ emissions across northern China's grasslands was approximately $100.66 \mathrm{Tg}$ C in 2010 , about $1 / 3$ of carbon fixed from the MODIS GPP product. Specially, the desert steppe exhibited the highest ratio, followed by the temperate meadow steppe, typical steppe and alpine meadow. Therefore, this work provides a novel framework to accurately predict the spatio-temporal patterns of $R_{e}$ over large areas, which can greatly reduce the uncertainties in global carbon estimates and climate projections.

Keywords: Ecosystem respiration, Grassland, MODIS, Piecewise regression

*Correspondence: yupujia@swu.edu.cn

${ }^{1}$ State Cultivation Base of Eco-agriculture for Southwest Mountainous Land, Southwest University, Chongqing 400715, China

Full list of author information is available at the end of the article

\section{Background}

Although the terrestrial biosphere absorbs nearly a quarter of anthropogenic $\mathrm{CO}_{2}$ emissions and plays a critical role in mitigating global climate warming, the land $\mathrm{C}$ sequestration potential of different ecosystems remains highly uncertain, leading to large uncertainties in future climate projections $[1,2]$. During the past several decades, substantial advances have allowed for spatially

c) The Author(s) 2020. This article is licensed under a Creative Commons Attribution 4.0 International License, which permits use, sharing, adaptation, distribution and reproduction in any medium or format, as long as you give appropriate credit to the original author(s) and the source, provide a link to the Creative Commons licence, and indicate if changes were made. The images or other third party material in this article are included in the article's Creative Commons licence, unless indicated otherwise in a credit line to the material. If material is not included in the article's Creative Commons licence and your intended use is not permitted by statutory regulation or exceeds the permitted use, you will need to obtain permission directly from the copyright holder. To view a copy of this licence, visit http://creativeco mmons.org/licenses/by/4.0/. The Creative Commons Public Domain Dedication waiver (http://creativecommons.org/publicdomain/ zero/1.0/) applies to the data made available in this article, unless otherwise stated in a credit line to the data. 
continuous, long-term estimation of terrestrial gross primary productivity (GPP) based on the satellite remote sensing data, climate data and ecosystem models [3-6]. However, net ecosystem $\mathrm{C}$ budget depends upon the balance of $\mathrm{C}$ fixation through vegetation photosynthesis and $C$ loss from ecosystem respiration $\left(R_{e}\right)[7,8]$, which requires accurate estimates of not only GPP but also $R_{e}$ across biomes.

Actually, terrestrial $R_{e}$ from the biosphere to the atmosphere represents a large component of annual carbon budget, which even exceeds the amount of GPP $[9,10]$. It has excited much interest in evaluating the balance between GPP and $R_{e}$ on regional to global scales [11-13], because small fluctuations in either component caused by natural or human disturbances can ameliorate or exacerbate the buildup of $\mathrm{CO}_{2}$ in the atmosphere [14-16]. Particularly, $R_{e}$ is sensitive to the environmental factors and is highly spatio-temporally heterogeneous across scales $[17,18]$, which made it far poorly understood owing to the complicated interactions among physical, chemi$\mathrm{cal}$, and biological variables in the respiration processes, including autotrophic respiration $\left(R_{a}\right)$ from vegetation itself and heterotrophic respiration $\left(R_{h}\right)$ from diverse soil microbiota [19]. Therefore, accurate quantification of the C emissions through $R_{e}$ is crucial to understand its effect on climate change and global carbon dynamics.

With the development of global FLUXNET community based the eddy covariance (EC) technique across terrestrial ecosystems, it has been possible to continuously monitor the seasonal and interannual variations of carbon fluxes between the biosphere and the atmosphere, which can be further divided into GPP and $R_{e}$ according to the nighttime based [20] and daytime based flux-partitioning methods [21]. However, the in situ observations are generally implemented at field scale with low areal coverage $\left(<1 \mathrm{~km}^{2}\right)$ and high cost of constructing and maintaining flux towers [22-24]. The availability of spatially continuous data of ecosystem properties and environmental variables important for $R_{e}$ provides an alternative approach for the large-area estimates. Currently, how to upscale the field-measured data using remote sensing (RS) information is urgently needed for understanding regional and global patterns of ecosystem $R_{e}$.

Several studies have recently been conducted to model the spatial distribution of soil respiration $\left(R_{s}\right)$ at alpine grasslands [25] and forests [26, 27] using the satellite-based products including land surface temperature (LST) and spectral vegetation index (NDVI or EVI) or leaf area index (LAI). By incorporating the terrain information, Berryman et al. [28] estimated $R_{s}$ in a typical of the Southern Rocky Mountains with a coefficient of determination $\left(R^{2}\right)$ of 0.45 . Jägermeyr et al. [29] firstly developed the models of global $R_{e}$ according to forested and non-forested biomes. However, the classification system means that parameterization may not take into account the wide variety of ecosystems on the earth [31]. Ai et al. [17] also proposed an empirical yet physiologically based model with $R^{2}$ and RMSE of 0.55 and $1.67 \mathrm{~g} \mathrm{C} \mathrm{m}^{-2} \mathrm{~d}^{-1}$ respectively, which is capable of retrieving the patterns in $R_{e}$ at the global scale. But the model cannot be transferred well to specific ecosystems, and may particularly be inaccurate in hydrologically sensitive areas owing to lack of water index affecting $R_{e}$. Nevertheless, previous studies have implied the significant correlations between grassland respiration and vegetation growth status [25], as well as the environmental variables such as $\operatorname{LST}[15,17,30]$ from the time-series satellite data.

Grasslands are the dominant landscape in China and account for $40 \%$ of the national land area. Geographically, approximately $78 \%$ of the grasslands in China exist in the northern temperate and alpine zones, constituting an integral part of the Eurasian grassland ecosystem [32, 33]. Due to their large carbon content, grasslands account for one-third of the global terrestrial carbon stock, second only to the forest ecosystem [34, 35], and play a key role in China's terrestrial carbon cycle. Zhang et al. [5] found that temperate grasslands in northern China have the potential to sequester carbon, but the capacity of carbon sequestration relies on grassland types and local environmental conditions. Further analysis revealed that the water availability is the dominant environmental factor regulating the annual carbon budget [36]. Extreme climate events such as drought can significantly reduce the net carbon uptake of grasslands. Moreover, it is predicted that heat waves and droughts will become more frequent in the 21 st century [37], which may lead to a general decrease in vegetation productivity in these grassland systems of northern China. Although several studies suggested that grasslands might be weak $\mathrm{C}$ sinks or near equilibrium [5, 38], as the main constraint on $C$ budget, a deep understanding of $R_{e}$ is helpful to project climate change-terrestrial $C$ feedback over different grassland ecosystems. Specially, the goals of this study were: (1) to analyze the differences of carbon released by $R_{e}$ as well as the dominant environmental variables across the temperate meadow steppe, typical steppe, desert steppe and alpine meadow, respectively; (2) to develop rule-based piecewise regression models to map $R_{e}$ of diverse grasslands by integrating time-series MODIS products and tower-based observations; and (3) to map the spatial patterns of annual mean $R_{e}$ for the grassland ecosystems in northern China. 


\section{Methods and materials Description of the study area}

The study was conducted in the grassland ecosystems of northern China, which is characterized by the arid and semi-arid continental monsoon climate with the highest temperature and rainfall period in summer. Following the east-to-west precipitation gradient, the temperate grasslands in northern China alter longitudinally from meadow steppes in the northeast, through typical steppes in the middle, and to desert steppes in the dry northwest. Alpine meadows are the dominant vegetation type in the Tibetan Plateau zone. These grasslands usually start to grow in early May and wither in late September with the peak biomass in July or August, which provide an important resource for livestock production and global carbon sequestration $[5,33]$.

During recent years, a series of EC-based flux towers have been installed by the Coordinated Observation and Synthesis in Arid and Semi-arid China (COSAS), as a part of China Flux Observation and Research Network (ChinaFLUX), which can be used to observe the carbon and water exchanges between the atmosphere and these grasslands in the ecologically fragile areas of northern China (Fig. 1). In total of 11 flux sites are used in the study, which represent the most prevalent types of grassland ecosystems and a wide range of spatial, ecological, and climatic conditions, including two meadow steppe sites, two typical steppe sites, two desert steppe sites and five alpine meadow sites. Detailed descriptions of these flux sites can be found in the associated literature (Table 1).

\section{Processing of the EC-based flux data}

Both the EC system and the automatic meteorological station were mounted at these grassland sites, which acquired the continuous observations of site-level carbon fluxes (NEE), as well as the relevant climate data, including solar radiation $\left(R_{g}\right)$, air and soil temperatures $\left(\mathrm{T}_{\mathrm{a}}\right.$ and $\mathrm{T}_{\mathrm{s}}$ ), relative humidity, soil water content (SWC), precipitation (P) and vapor pressure deficit (VPD). Each EC system was comprised of a three-dimensional sonic anemometer (CSAT3, Campbell Scientific, UT, USA) and a $\mathrm{Li}-7500$ open path $\mathrm{CO}_{2}$ and $\mathrm{H}_{2} \mathrm{O}$ gas analyzer (LI-COR Inc., NE, USA). Raw data were continuously recorded at a frequency of $10 \mathrm{~Hz}$ on a CR5000 (Campbell Scientific) data logger. The processing procedures including spike detection and despiking, two-dimensional coordinate rotation, time delay removal of $\mathrm{H}_{2} \mathrm{O}$ and $\mathrm{CO}_{2}$, virtual temperature correction, density effects (WPL correction) and frequency response corrections were completed using the improved EdiRe software package (developed by the University of Edinburgh) to produce a halfhour flux dataset [39]. However, owing to instrument malfunctions, power failure, and severe weather conditions, approximately $25 \%$ of the 1 -year observations were lost. Therefore, it was necessary to interpolate these gaps with a standardized gap-filling algorithm. Then, the timeseries NEE flux data were partitioned into GPP and $R_{e}$, separately. In this study, the half-hourly $R_{e}$ data provided by flux-tower measurements were integrated to the daily time scale, and then averaged over each 8-day period to match the 8-day composite of the MODIS products. The procedures including gap-filling and flux partitioning, were completed using the new R-based package (REddyProc) maintained by the Max Planck Institute for Biogeochemistry [40].

Currently, there are mainly two methods implemented for flux-partitioning: (1) $R_{e}$ is estimated from the nighttime temperature and extrapolated to daytime [20] and (2) the light-response curve is fit to daytime NEE measurements and $R_{e}$ is estimated from the intercept of the ordinate [21], which can avoid the use of potentially problematic nighttime data. The latter approach was chosen for flux partitioning because it uses a hyperbolic light-response curve algorithm, modified to account for the temperature dependency of respiration and the VPD limitation of photosynthesis [41]. Including the VPD dependency strongly improved the model's ability to reproduce the asymmetric diurnal cycle during periods with high VPD, and enhances the reliability of $R_{e}$ estimates given that the reduction of GPP by VPD may be otherwise incorrectly attributed to higher $R_{e}$. More details can be seen in the associated references.

\section{MODIS products and processing}

$R_{e}$ is generally comprised of two sources of respiration: $R_{a}$ from maintenance respiration and growth respiration, and $R_{h}$ from rhizomicrobial respiration and microbial decomposition of plant residues and other soil organic matter [42, 31]. Thus, it is strongly affected by plant growth status and climate conditions. This study used the enhanced vegetation index (EVI) and leaf area index (LAI), as well as the land surface water index (LSWI), and mean value of daytime and nighttime temperatures (LST) to represent the vegetation and climate-related variables.

All variables were derived from the time-series MODIS data, which can avoid the complications and difficulties associated with merging disparate data sources. The 8-day land surface reflectance (MOD09A1, V6, with resolution of $500 \mathrm{~m}$ ), LAI product (MOD15A2, V6, with resolution of $500 \mathrm{~m}$ ) and LST data (MOD11A2, V6, with resolution of $1 \mathrm{~km}$ ) were downloaded from the NASA's Earth Observing System Data and Information System (https://search.earthdata.nasa.gov). We only used the data described as good quality in the quality layer. These remote sensing-based products were re-sampled 


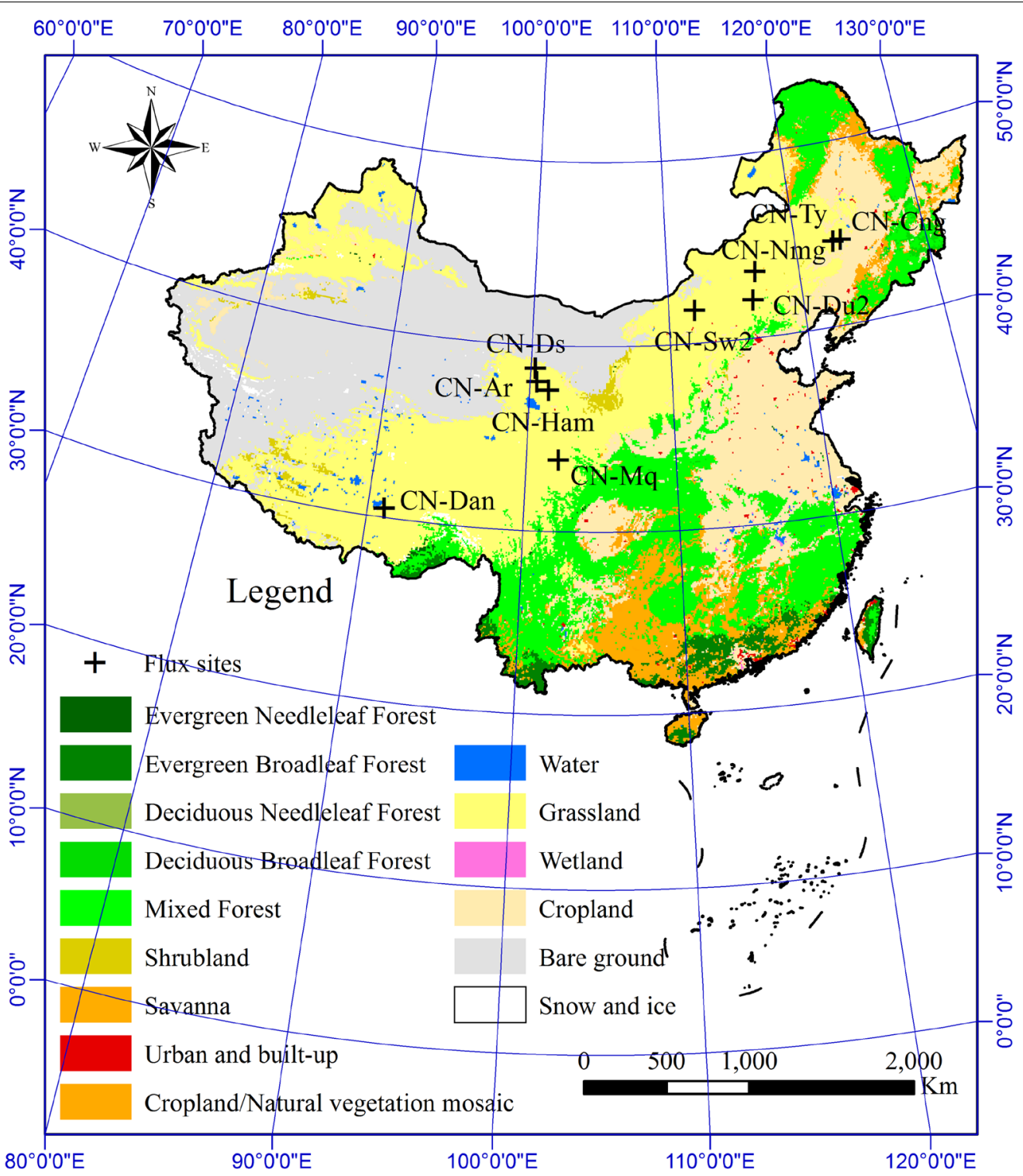

Fig. 1 Spatial location and distribution of the grassland flux sites used in the present study. The base map is derived from MODIS land cover product (MCD12Q1 C5, 500 m resolution) based on the International Geosphere Biosphere Programme (IGBP) global vegetation classification scheme in 2010. The detailed descriptions of these flux sites including CN-Cng, CN-Nmg, CN-Du2, CN-Hzz, CN-Sw2, CN-Ham, CN-Ar, CN-Ds, CN-Dan, CN-Ty and CN-Mq can be seen in Table 1

to a spatial resolution of $1 \mathrm{~km}$, and the data where corresponded to the geographical location of each flux site were extracted for model development. In addition, the vegetation type map at $1 \mathrm{~km}$ resolution in 2010 was obtained from Nanjing Institute of Geography and Limnology, Chinese Academy of Science. The product specifically classified grasslands in China into temperate meadow steppe, typical steppe, desert steppe and alpine meadow, which can meet the needs to estimate $R_{e}$ across different grassland types in this study. Then, all these data were used to develop models and map the spatio-temporal patterns of $R_{e}$ in grassland ecosystems in northern China.

\section{Statistical analyses}

To reveal the dominant environmental factors controlling the variability in $R_{e}$ on an 8-day time scale over the whole year and different phenological periods (growing season $v s$ dormant season) at these four different grassland ecosystems, the Pearson correlation coefficient $(r)$ was 


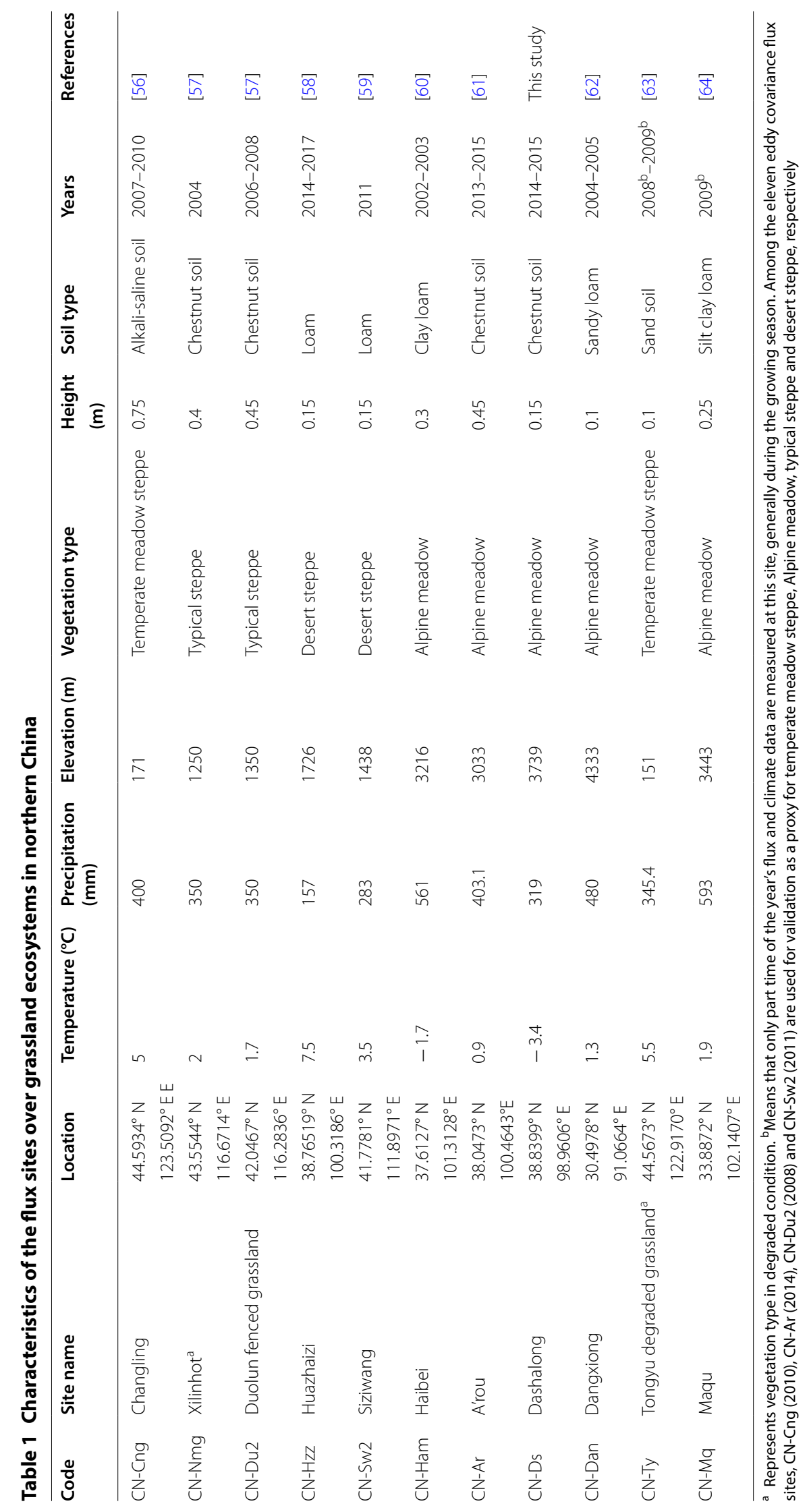


calculated to examine the relationships between site-level $R_{e}$ observations and these vegetation and climate-related variables. As these grasslands usually start to grow in early May and wither in late September, the growing period and dormant period were defined from WOY 16 to 34 and the rest of 1 year (WOY 1 to 15 , and WOY 35 to 46), respectively. Then, we aimed to develop a rule-based piecewise regression model to capture the seasonal variations in $R_{e}$ of temperate meadow steppe, typical steppe, desert steppe and alpine meadow in northern China. For each grassland type, the training set and test set of these flux data were instructed in Table 1. The study defined the model developed directly from the entire year as model 1, and the model from the growth period and dormant season as model 2. The model's accuracy was evaluated using two widely-used indicators: $R^{2}$ and the root-mean-square error (RMSE). The best model generally had the highest $R^{2}$ and lowest RMSE values. Finally, the optimal models were used to map the spatial patterns of annual mean $R_{e}$ for the grasslands in northern China. All statistical analyses were performed using SPSS 19.0 (IBM, Chicago, IL, USA). In addition, the MODIS Reprojection Tool (MRT) and the Interactive Data Language (IDL) in ENVI 5.3 were used to process over 2000 scenes of MODIS data and large-area estimation.

\section{Results}

\section{Differences of annual mean $R_{e}$ across grasslands}

Multi-year mean $R_{e}$ of the temperate meadow steppe, typical steppe, desert steppe and alpine meadow ecosystems in northern China were exhibited in Fig. 2 with apparent differences in magnitude. It revealed that $\mathrm{C}$ emissions by $R_{e}$ were mainly concentrated in the growing season, which was even about twice and seven times of $R_{e}$ during the dormant period for desert steppe and the other grasslands, respectively. The low $R_{e}$ of desert steppe throughout the year can be ascribed to relatively sparse vegetation coverage. This study also found that during non-growing season, only small differences in $R_{e}$ existed among these grassland types. Generally, typical steppe exhibited the strongest $R_{e}$ of $1.08 \pm 0.23 \mathrm{~g} \mathrm{C} \mathrm{m}^{-2}$ $\mathrm{d}^{-1}$, followed by temperate meadow steppe $(1.03 \pm 0.10 \mathrm{~g}$ $\left.\mathrm{C} \mathrm{m}^{-2} \mathrm{~d}^{-1}\right)$ and alpine meadow $\left(1.05 \pm 0.48 \mathrm{~g} \mathrm{C} \mathrm{m}^{-2} \mathrm{~d}^{-1}\right)$, and undoubtedly desert steppe had the weakest $R_{e}$. These analyses again emphasized the importance to quantify the patterns of grassland $R_{e}$ separately for large-area estimation.

\section{Seasonal variations in $\mathbf{R}_{\mathbf{e}}$ and environmental controls}

Seasonal dynamics in $R_{e}$ as well as the vegetation and climate-related variables across the four grassland ecosystems were illustrated in Figs. 3 and 4 . It implied that except the desert steppe site (CN-Hzz), $R_{e}$ of the other

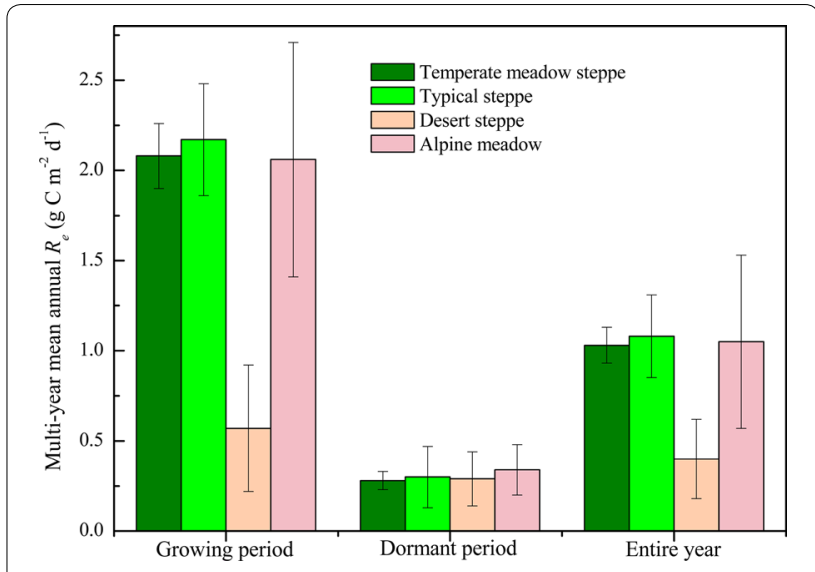

Fig. 2 Comparisons of multi-year mean $R_{e}$ during the growing period, dormant period and the entire year across grasslands in northern China. Error bars represent one standard error

three grassland types exhibited an apparent single-peak pattern. As the temperature rose in spring, $R_{e}$ gradually increased with plant growth, and reached the peak in July or August. However, the peak periods came earlier in typical steppe (CN-Nmg) at about week of year-WOY 23, followed by temperate meadow steppe (CN-Cng, WOY 25) and alpine meadow (CN-Ham, WOY 30). Natural rainfall generally occurred in summer with large fluctuations around the year. Contrastingly, relatively smooth SWC can reflect the true water availability. As a proxy of vegetation response to environmental variables, EVI and LAI exhibited consistent trends as $R_{e}$. Several periods of the remote-derived LSWI in winter were quite large due to the snow cover on and under the grasslands.

Table 2 revealed that almost all variables were strongly correlated to $R_{e}$ without considering the phenology information. However, during the dominant growth period for respiration in temperate meadow steppe, typical steppe and alpine meadow, only temperature $\left(\mathrm{T}_{\mathrm{a}}\right.$ and $\left.\mathrm{T}_{\mathrm{s}}\right)$ and SWC strongly and positively affected the variability in $R_{e}$. In the desert steppe, $R_{e}$ was found to be exerted a strong effect by SWC across growing and dormant seasons, which highlighted the water condition rather than temperature as the most important controlling factor in the extremely dry ecosystems. All the remotely-sensed vegetation indexes and climate-related LST and LSWI exhibited strong correlations, implying great potential to quantify the variability in $R_{e}$ using $\mathrm{RS}$ technique.

\section{Model development for quantitative remote sensing}

By integrating site-level $R_{e}$ observations and time-series MODIS products, the study developed the optimal models for capturing the variability in $R_{e}$ of different grasslands using the stepwise multiple regression method 


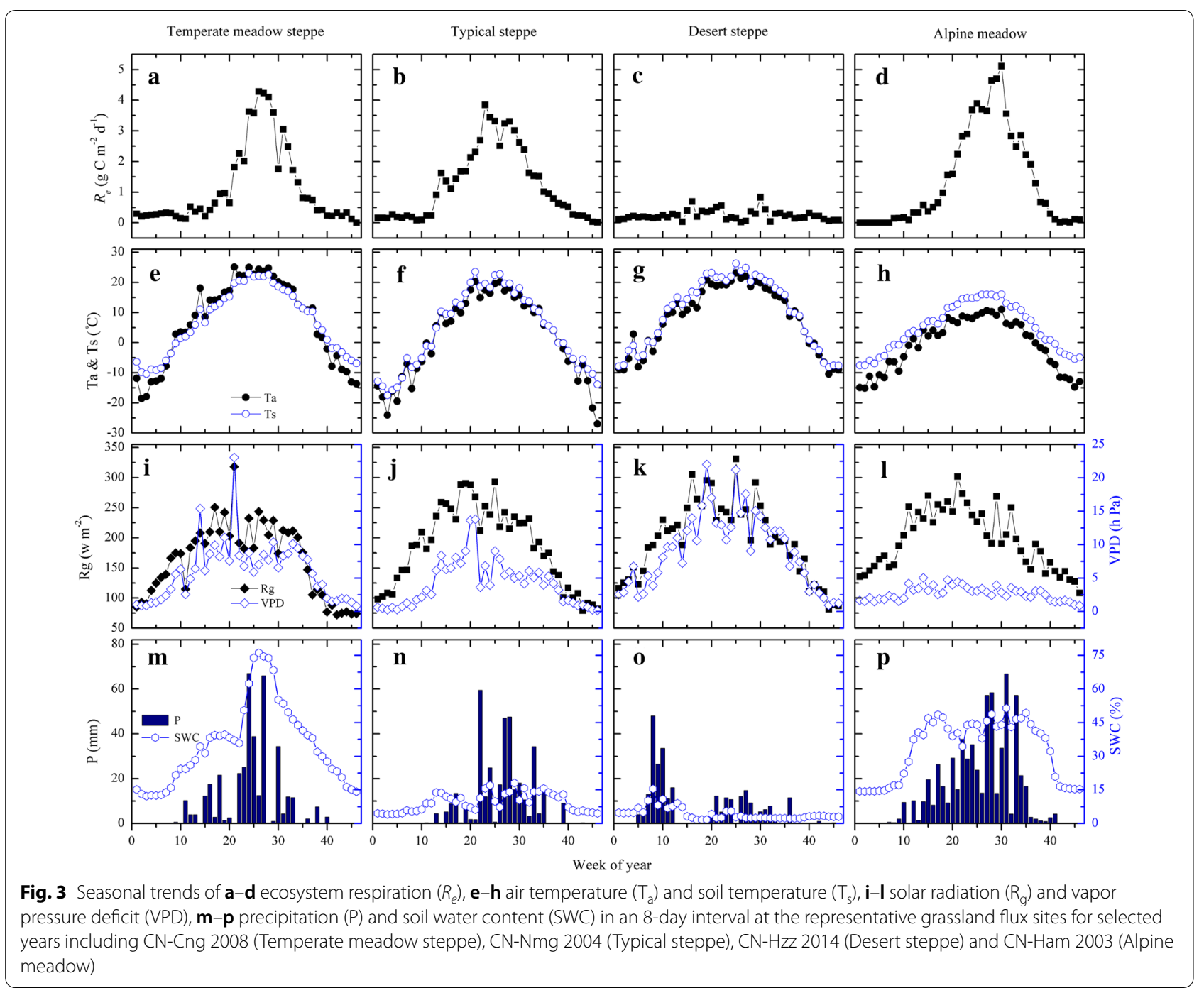

(Table 3). Mainly two models were proposed with good performances. Generally, the model 2 established from the growth period and dormant season separately had relatively higher accuracy in estimating $R_{e}$ than that directly from the whole year (model 1). Besides the desert steppe, $R^{2}$ and RMSE of the other grasslands varied from 0.77 to 0.88 and from 0.41 to $0.67 \mathrm{~g} \mathrm{C} \mathrm{m}^{-2} \mathrm{~d}^{-1}$, respectively. The model with only LAI as an explanatory variable also got good estimates for the desert steppe. Figure 5 further certified that the model promised well to estimate 8-day $R_{e}$ and captured the broad trend of seasonal patterns, especially for the $R_{e-}$ model 2 , whereas the $R_{e-}$ model 1 caused individual abnormal $R_{e}$ estimates in wintertime. In spite of good accuracy, the RS-based models remained lacking of skills to capture abrupt changes in $R_{e}$ during the summertime growing season.

Meanwhile, this study evaluated the model's performance on annual mean $R_{e}$ across these four grasslands.
Figure 6 revealed that the remotely-derived products slightly underestimated $R_{e}$ at the temperate meadow steppe and desert steppe sites, but overestimated $R_{e}$ at the typical steppe and alpine meadow sites. The $R_{e-}$ model 1 had superior $R_{e}$ estimates with mean bias of $9.6 \%$ at the typical steppe site, while $R_{e-}$ model 2 only had an underestimation of $6.2 \%$ at the temperate meadow steppe site. Both models had similar accuracy at the desert steppe and alpine meadow sites.

\section{Spatial patterns of satellite-derived $\mathbf{R}_{\mathbf{e}}$}

The study mapped the spatial distribution of annual mean $R_{e}$ for grasslands in northern China using the proposed regression models (Fig. 7), which were extrapolated from the 8-day $R_{e}$ estimates throughout the year of 2010. Generally, our results showed a declining trend from the southeast to the northwest direction. The highest $R_{e}$ usually occurred in the temperate meadow 


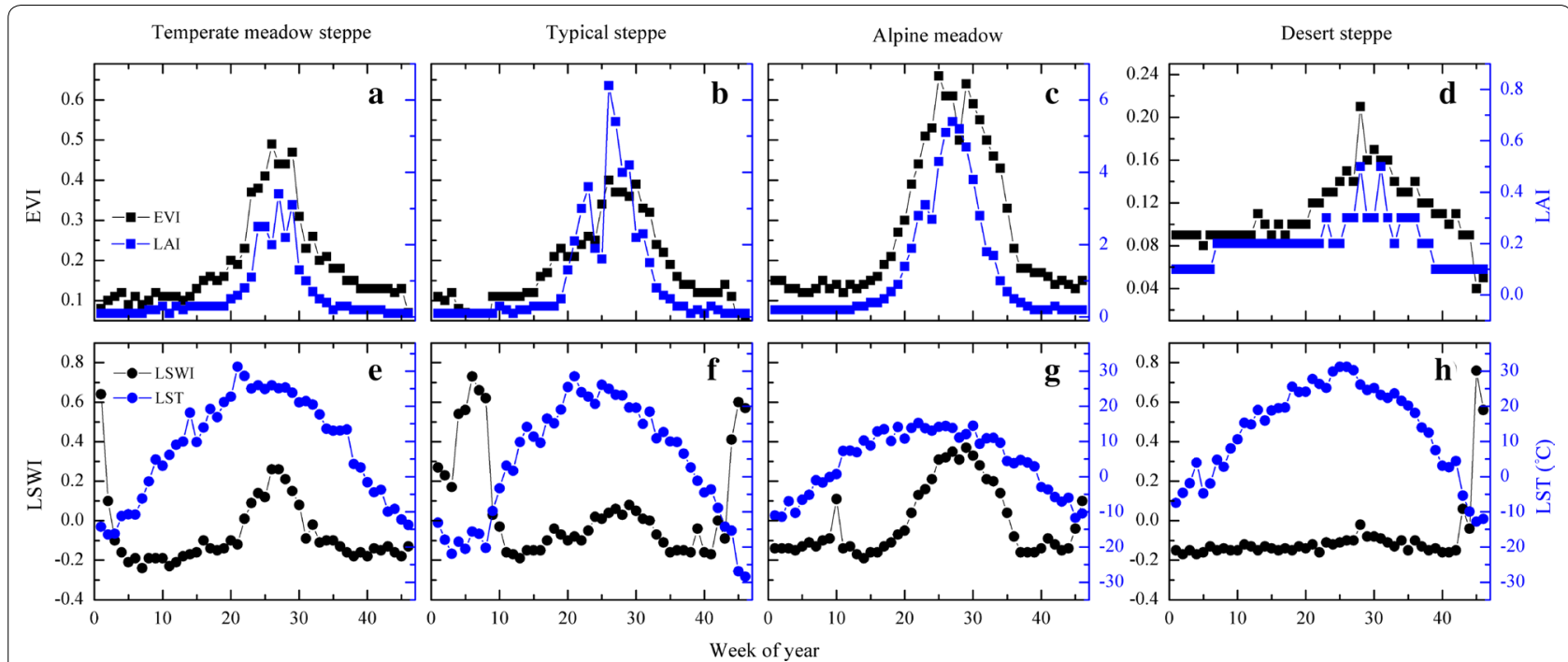

Fig. 4 The seasonal dynamics of 8-day EVI, LAI, LSWI and LST at the representative grassland flux sites for selected years including CN-Cng 2008 (Temperate meadow steppe), CN-Nmg 2004 (Typical steppe), CN-Hzz 2014 (Desert steppe) and CN-Ham 2003 (Alpine meadow)

Table 2 Pearson correlation analysis between 8-day $R_{e}$ and the controlling environmental factors across the four grassland ecosystem types

\begin{tabular}{|c|c|c|c|c|c|c|c|c|c|c|c|}
\hline Grassland type & Period & $\begin{array}{l}R_{g} \\
\left(W / m^{2}\right)\end{array}$ & $\begin{array}{l}\mathrm{T}_{\mathrm{a}} \\
\left({ }^{\circ} \mathrm{C}\right)\end{array}$ & $\begin{array}{l}\mathrm{T}_{\mathrm{s}} \\
\left({ }^{\circ} \mathrm{C}\right)\end{array}$ & $\begin{array}{l}\text { VPD } \\
(\mathrm{h} \mathrm{Pa})\end{array}$ & $\begin{array}{l}P \\
(\mathrm{~mm})\end{array}$ & $\begin{array}{l}\text { SWC } \\
(\%)\end{array}$ & EVI & LAI & LSWI & $\begin{array}{l}\text { LST } \\
\left({ }^{\circ} \mathrm{C}\right)\end{array}$ \\
\hline \multirow[t]{3}{*}{ Temperate meadow steppe } & Growing & -0.115 & $0.538^{a}$ & $0.613^{a}$ & $-0.287^{b}$ & $0.252^{b}$ & $0.351^{a}$ & $0.745^{a}$ & $0.692^{a}$ & $0.704^{a}$ & $0.371^{a}$ \\
\hline & Dormant & $0.411^{a}$ & $0.707^{a}$ & $0.714^{a}$ & $0.685^{a}$ & $0.231^{b}$ & $0.625^{a}$ & $0.378^{a}$ & $0.635^{a}$ & $-0.269^{b}$ & $0.689^{\mathrm{a}}$ \\
\hline & Entire year & $0.570^{a}$ & $0.749^{a}$ & $0.786^{a}$ & $0.520^{a}$ & $0.459^{a}$ & $0.669^{a}$ & $0.869^{a}$ & $0.851^{a}$ & 0.093 & $0.721^{\mathrm{a}}$ \\
\hline \multirow[t]{3}{*}{ Typical steppe } & Growing & 0.073 & $0.760^{a}$ & $0.707^{a}$ & -0.149 & $0.568^{a}$ & $0.495^{a}$ & $0.721^{a}$ & $0.644^{a}$ & $0.748^{a}$ & $0.669^{a}$ \\
\hline & Dormant & $0.506^{a}$ & $0.554^{a}$ & $0.553^{a}$ & $0.579^{a}$ & $0.269^{b}$ & $0.571^{a}$ & $0.377^{a}$ & $0.451^{a}$ & -0.235 & $0.532^{a}$ \\
\hline & Entire year & $0.644^{a}$ & $0.776^{a}$ & $0.803^{a}$ & $0.581^{a}$ & $0.700^{a}$ & $0.644^{a}$ & $0.861^{a}$ & $0.794^{a}$ & -0.011 & $0.759^{a}$ \\
\hline \multirow[t]{3}{*}{ Desert steppe } & Growing & 0.138 & 0.171 & 0.261 & 0.193 & 0.197 & $0.538^{a}$ & $0.499^{a}$ & $0.621^{a}$ & $0.338^{b}$ & 0.110 \\
\hline & Dormant & 0.086 & 0.175 & 0.225 & 0.056 & -0.119 & $0.611^{a}$ & $0.296^{b}$ & 0.052 & -0.262 & 0.175 \\
\hline & Entire year & $0.370^{a}$ & $0.408^{a}$ & $0.449^{a}$ & $0.421^{a}$ & 0.101 & $0.475^{a}$ & $0.542^{a}$ & $0.653^{a}$ & -0.198 & $0.392^{a}$ \\
\hline \multirow[t]{3}{*}{ Alpine meadow } & Growing & $-0.224^{b}$ & $0.535^{a}$ & $0.531^{a}$ & 0.039 & 0.142 & $0.397^{a}$ & $0.764^{a}$ & $0.382^{a}$ & $0.739^{a}$ & $0.281^{b}$ \\
\hline & Dormant & $0.275^{b}$ & $0.652^{a}$ & $0.628^{a}$ & $0.379^{a}$ & $0.445^{a}$ & $0.630^{a}$ & $0.577^{a}$ & $0.566^{a}$ & $-0.206^{b}$ & $0.561^{a}$ \\
\hline & Entire year & $0.265^{b}$ & $0.629^{a}$ & $0.647^{a}$ & $0.325^{a}$ & $0.484^{a}$ & $0.565^{a}$ & $0.837^{a}$ & $0.548^{a}$ & $0.326^{a}$ & $0.531^{a}$ \\
\hline
\end{tabular}

${ }^{a}$ and $^{b}$ mean that correlations are significant at the 0.01 level and 0.05 level, respectively. $R_{g}, T_{a}, T_{s}, V P D, P$ and SWC are observed at the flux tower sites listed in Table 1. Time-series EVI, LAI, LSWI and LST data are derived from the corresponding MODIS products. All these data are at an 8-day interval

steppe under good hydrothermal conditions. However, the desert steppe and the Tibetan alpine meadow emitted relatively fewer $\mathrm{CO}_{2}$ through respiration. The total regional $R_{e}$ estimate in the northern China's grasslands during 2010 was about $100.66 \mathrm{Tg} \mathrm{C}$, which was approximately $1 / 3$ of the carbon uptake through plant photosynthesis with $332.08 \mathrm{Tg} C$ from the MODIS GPP product. Specially, the ratio of $R_{e}$ to GPP exhibited the highest value in the desert steppe (88.6\%), followed by the temperate meadow steppe $(36.9 \%)$ and typical steppe (21.5\%), with the lowest ratio in the alpine meadow of $18.0 \%$.

\section{Discussion}

Along the east-west precipitation gradient in northern China, a wide variety of grasslands constitute the dominant landscape in servicing the ecological environment and socio-economics of the region and in supporting diverse species of plants and animals [32]. The meadow steppes usually occur in the most moist and fertile sites among the four grassland ecosystem types, typically in areas with annual precipitation of about $450 \mathrm{~mm}$. The typical steppes are developed under a semi-arid climate in the temperate zone with annual precipitation of around $350 \mathrm{~mm}$ and the plant species are 
Table 3 Regression analysis of 8-day $R_{e}$ and the associated MODIS-derived products across the four grassland ecosystems using the stepwise multiple regression method

\begin{tabular}{|c|c|c|c|c|c|c|c|c|c|c|}
\hline \multirow[t]{2}{*}{ Grassland type } & \multirow[t]{2}{*}{ Period } & \multicolumn{5}{|c|}{ Regression models } & \multicolumn{2}{|c|}{ Training set } & \multicolumn{2}{|c|}{ Test set } \\
\hline & & Constant & EVI & LAI & LSWI & LST & $R^{2}$ & RMSE & $R^{2}$ & RMSE \\
\hline \multirow[t]{3}{*}{ Temperate meadow steppe } & Growing & 1.088 & 4.078 & - & 3.743 & - & 0.57 & 0.72 & 0.77 & 0.45 \\
\hline & Dormant & 0.064 & 2.362 & - & 0.268 & 0.014 & 0.61 & 0.13 & & \\
\hline & Entire year & -0.619 & 8.487 & - & - & 0.018 & 0.80 & 0.51 & 0.71 & 0.63 \\
\hline \multirow[t]{3}{*}{ Typical steppe } & Growing & 0.561 & - & - & 6.058 & 0.096 & 0.72 & 0.60 & 0.88 & 0.41 \\
\hline & Dormant & 0.044 & 3.463 & - & 0.659 & 0.021 & 0.41 & 0.26 & & \\
\hline & Entire year & -0.083 & 5.633 & - & 1.419 & 0.040 & 0.84 & 0.49 & 0.81 & 0.50 \\
\hline \multirow[t]{3}{*}{ Desert steppe } & Growing & 0.213 & - & 0.758 & - & - & 0.39 & 0.32 & 0.50 & 0.21 \\
\hline & Dormant & 0.122 & 2.035 & - & - & -0.003 & 0.11 & 0.17 & & \\
\hline & Entire year & 0.190 & - & 0.775 & - & - & 0.43 & 0.25 & 0.45 & 0.27 \\
\hline \multirow[t]{3}{*}{ Alpine meadow } & Growing & -0.321 & 7.198 & -0.208 & 2.854 & - & 0.73 & 0.98 & 0.85 & 0.67 \\
\hline & Dormant & -0.264 & 3.826 & 0.897 & 0.804 & 0.019 & 0.65 & 0.20 & & \\
\hline & Entire year & -0.520 & 6.947 & - & 1.318 & 0.020 & 0.81 & 0.67 & 0.83 & 0.69 \\
\hline
\end{tabular}

Time-series EVI, LAI, LSWI and LST data are derived from the corresponding MODIS products. All data are at an 8-day interval. The training set and test set of these flux sites are instructed in Table 1. When using the stepwise multiple regression method to develop models, only the best is exhibited here. The model's performance was evaluated using the site-level flux measurement
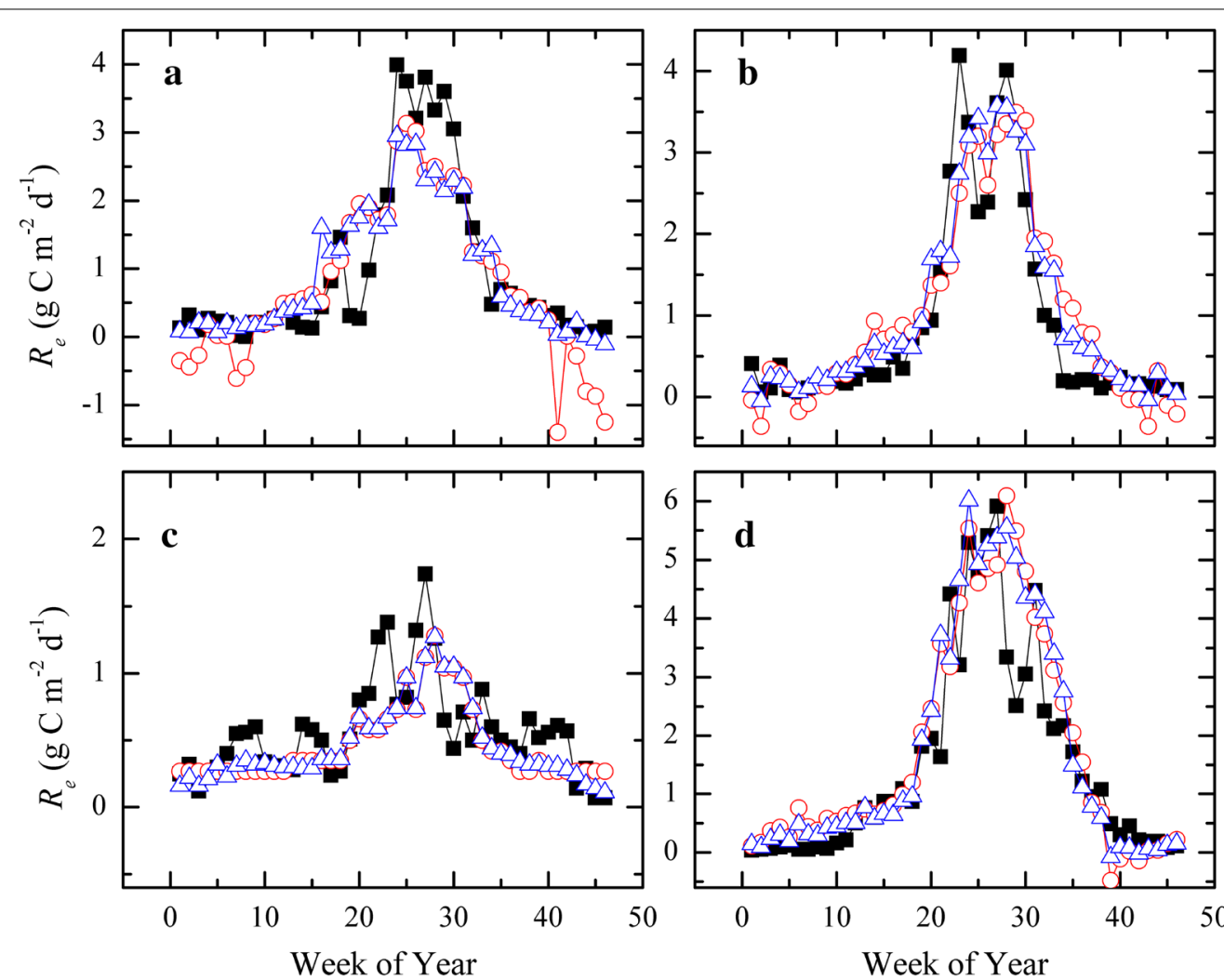

$\longrightarrow-R_{e-}$ observed $\multimap-R_{e-}$ model1 $\smile-R_{e-}$ model 2

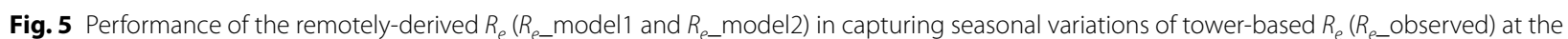
temperate meadow steppe (a), typical steppe $(\mathbf{b})$, desert steppe $(\mathbf{c})$ and alpine meadow $(\mathbf{d})$ sites, respectively 


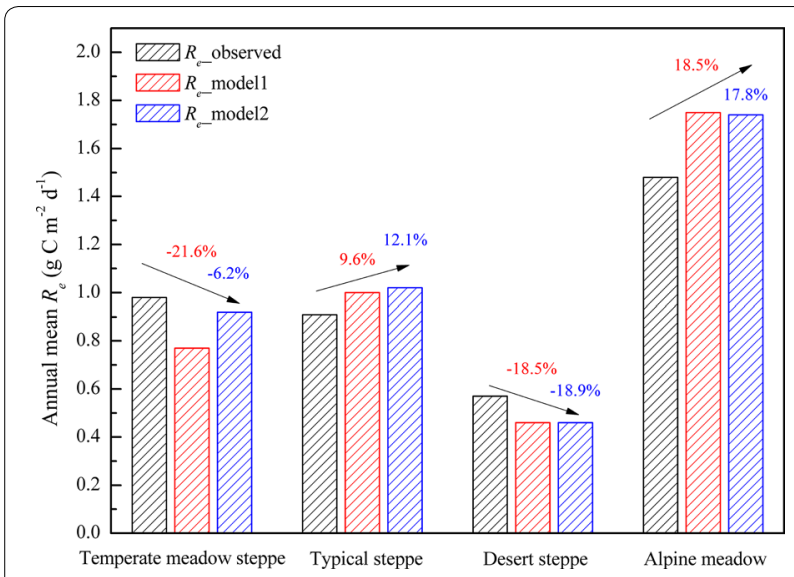

Fig. 6 Comparisons of annual mean $R_{e}$ observations and the remotely-derived products across the temperate meadow steppe, typical steppe, desert steppe and alpine meadow sites

characteristically drought-tolerant. The desert steppes are the most arid grassland type, occurring in areas with annual precipitation between 150 and $250 \mathrm{~mm}$ under the influence of continental climate. Alpine steppes are found between 2300 and $5300 \mathrm{~m}$ a.s.l. in southwestern China. The common construction plant species are coldand drought-tolerant grasses and small shrubs. Arid and semiarid ecosystems are often overlooked in this regard because of their spatially sparse vegetation and fragile environmental conditions [43, 44]. In fact, the grassland ecosystems are not only economically important, but recent work has shown water-limited systems to drive the interannual variability in the global $\mathrm{C}$ cycle significantly $[45,46]$. Therefore, a deep understanding of the $C$ sequestration potential as well as environmental controls over the northern China's grasslands is vital for reducing the uncertainty in future climate projections given the large area of grasslands.

Accurate quantification of the main $\mathrm{C}$ fluxes across terrestrial ecosystems is crucial to our understanding of global carbon balance [23, 47]. Till now, there are fewer successful models of $R_{e}$ compared to GPP particularly using the RS data directly $[29,48]$. Reichstein et al. [49] found that soil water and temperature were good predictors for $R_{s}$, and adding LAI as a proxy for productivity further improved the accuracy. This study was based on closed-chamber data from forest and shrubland sites across Europe and North America, but it was suggested that the variables could easily be acquired from RS data. Anderson et al. [50] used a model which calculated soil moisture from microwave sensing, soil temperature from thermal imaging, and LAI, showed good agreement with tower flux data over pasture land in Oklahoma. However, model development over such a small area is unlikely to generate a model which is applicable to other ecosystems or climates, and more validation work is also needed. In spite of this, subsequent studies have suggested that the strong relationships between $R_{s}$ and $R_{e}$ and GPP [26], LST $[17,25,48]$ from the time-series RS data.

Changes in temperature and water availability, and thus climate change, are likely to be significant drivers of the future $\mathrm{C}$ balance of land systems and their feedbacks to climate change. Grasslands in the arid and semi-arid regions are ecologically fragile and sensitive to climate change and human disturbances, especially to the changes in precipitation [51]. The precipitation in arid and semi-arid regions is highly variable both temporally and spatially. Fluctuations in carbon budget have been found to be closely associated with interannual and intraannual variations in precipitation in arid and semi-arid ecosystems, and persistent drought has caused a general decrease in vegetation productivity in the grassland systems of northern China [5]. These work also demonstrated that water condition is an important environmental indicator for the estimates of $R_{e}$ in the grassland ecosystems. Soil moisture affects $R_{e}$ processes in various ways, including the growth and development of both aboveground vegetation and roots, growth and activity of microbial populations, in addition to gas transport throughout soils [52, 53]. Green et al. [2] also emphasize that the capacity of continents to act as a future carbon sink critically depends on the response of $C$ fluxes to soil moisture. The study used the LSWI derived from the shortwave infrared (SWIR) and the near infrared (NIR) bands of MODIS data to represent land surface water condition, and got reasonably good performance. Actually, LSWI is different from soil moisture (SWC) because most information of LSWI reflects the total amount of liquid water in vegetation [54]. An interesting avenue of future work would be to consider employing the soil moisture data from the Advanced Microwave Scanning Radiometer-Earth Observing System (AMSE-E) [55]. The problem with many of these studies, however, is that they are too narrow for comparison. They consider one particular site in one particular ecosystem, or attempt to create a global model often focus on a narrow range of only four or five ecosystem types [17, 29]. Grasslands and their huge variety of types are almost never included as a separate category in remote sensing models of carbon flux, and as such are certain to be over or under-estimated. Ge et al. [30] proposed similar models to evaluate grassland $R_{e}$ at a regional scale by integrating flux measurements and the corresponding MODIS products. But this study simplified the grasslands in northern China by alpine grasslands and temperate grasslands. In fact, large differences existed among the temperate meadow steppe, typical steppe and desert steppe when exploring 


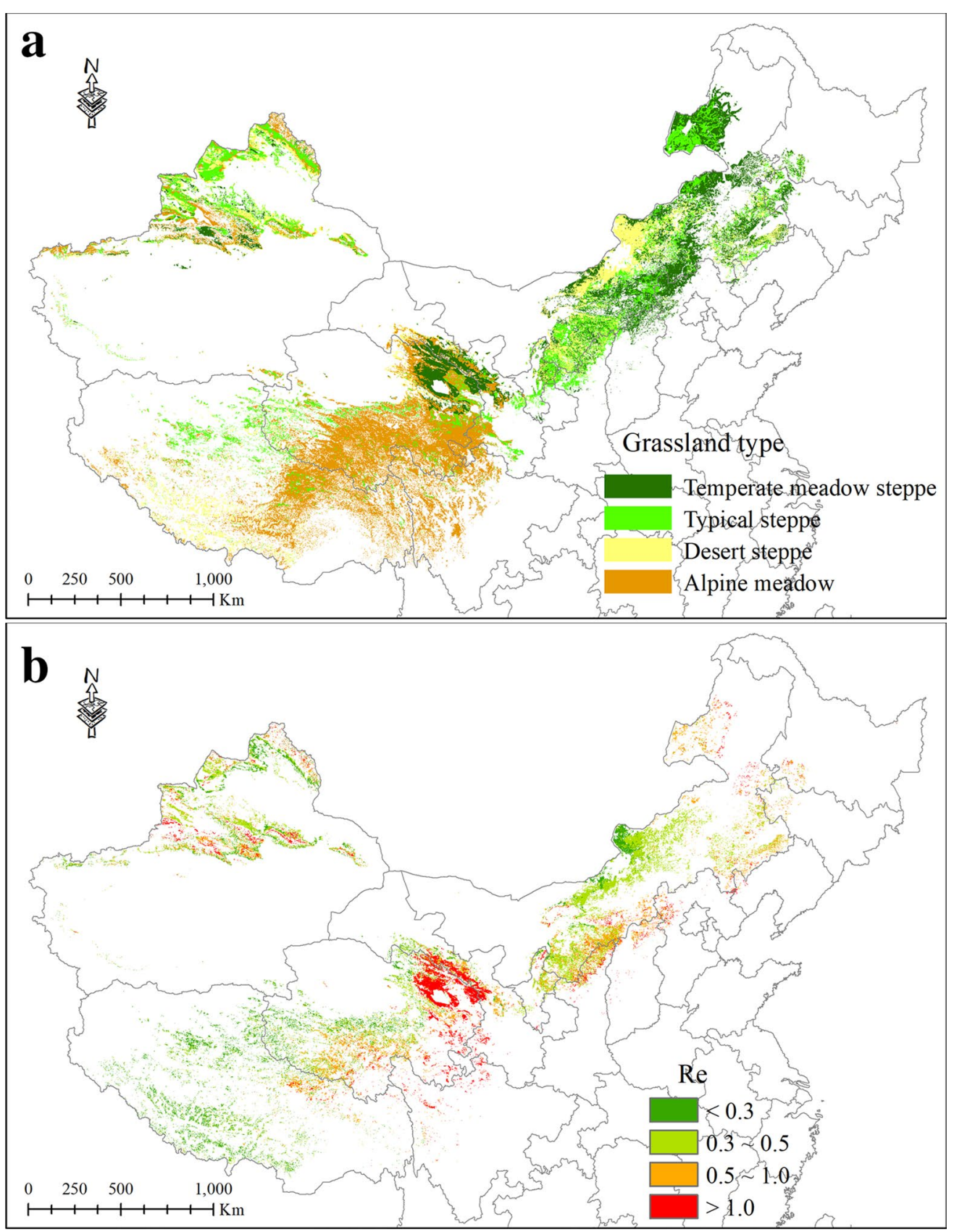

Fig. 7 Spatial patterns of grassland types (a) and annual mean $R_{e}(\mathbf{b})$ over the northern China's grasslands in 2010. The unit of $R_{e}$ is $\mathrm{g} \mathrm{C}^{-2} \mathrm{~d}^{-1}$

the dominant environmental controls and developing associated models. Meanwhile, the variability in $R_{e}$ rely on grassland types and local environmental conditions. Therefore, our research on remotely monitoring $R_{e}$ from various grasslands along a large-scale east-west transect across northern China can provide more information than previous studies.
Our results suggested that simple models relying entirely on spatial data have the potential to estimate $R_{e}$ over the diverse grassland ecosystems. This result provides a framework for the development of $R_{e}$ models aimed to obtain spatial pattern in $R_{e}$. Meanwhile, the models incorporating the phenology information generally provided better estimations. In this study, we simply separated the growing season and dormant season as 
these grasslands usually start to grow in early May and wither in late September. To acquire more specific phenological information of each pixel, the global land surface phenology metrics at yearly intervals (MCD12Q2) can be used for auxiliary analysis. But the models would be complicated for large-scale extrapolation owing to strong spatial heterogeneity. In addition, there is a need for more long-term studies in order to monitor the interannual variations of $R_{e}$ as well as the underlying mechanisms. The study calculated the spatial distribution of grassland $R_{e}$ in 2010 because we only have a period of classification data with detailed grassland types. The total of carbon emissions of $R_{e}$ across the northern China's grasslands was accumulated to $100.66 \mathrm{Tg} C$ during 2010, which was approximately $1 / 3$ of the regional carbon uptake through plant photosynthesis with $332.08 \mathrm{Tg} \mathrm{C}$ from the MODIS GPP product. Particularly, the carbon use efficiency was the highest in the alpine meadow, followed by the typical steppe, meadow steppe and desert steppe. However, this approach generally need large amounts of $R_{e}$ data to constrain parameters. The regression coefficients obtained at this study would not work well for other grassland sites with different climate, soil, and vegetation. Although we tried to establish the robust models for the temperate meadow steppe, typical steppe, desert steppe and alpine meadow using 11 flux sites, the representativeness of these limited sites presumably affected the general applicability of our predictive model. Thus, the current Coordinated Observation and Synthesis in Arid and Semi-arid China should be augmented by building more sites across a full range of grassland types.

Conclusion

On the basis of 24 EC-based years of flux measurements over 11 grasslands sites under a wide range of geographic, weather and ecological conditions, the study was an attempt to upscale site-level $R_{e}$ data to the northern China's grasslands including temperate meadow steppe, meadow steppe, desert steppe and alpine meadow, using the satellite-based RS data. The results demonstrated that the rule-based piecewise regression models can successfully estimate the seasonal variations in $R_{e}$ and provide a new framework to map the regional patterns of largescale $R_{e}$. The reduction of uncertainties in $R_{e}$ is crucial for projecting climate change impacts on terrestrial carbon cycling and future atmospheric $\mathrm{CO}_{2}$ concentrations. This work also offers an opportunity to further understand the environmental drivers controlling the variability in $R_{e}$. Specially, not only temperate but also soil water content, had a strong correlation with grassland $R_{e}$, which should not be neglected when developing the RS models for arid and semiarid ecosystems. Meanwhile, the models incorporating the phenology information generally performed better. The spatial patterns of $R_{e}$ across the northern
China's grasslands exhibited a distinctly declining trend from the southeast to the northwest, with a regional estimate of approximately $100.66 \mathrm{Tg} \mathrm{C}$ during 2010. With more periods of grassland classification information, future studies can even evaluate long-term land-use change and its impact on the large-scale $R_{e}$ of grasslands.

\begin{abstract}
Abbreviations
$R_{e}$ : Ecosystem respiration; GPP: Gross primary production; MODIS: Moderateresolution Imaging Spectroradiometer; $R_{a}$ : Autotrophic respiration; $R_{h}$ : Heterotrophic respiration; $\mathrm{EC:}$ Eddy covariance; $\mathrm{RS}$ : remote sensing; $R_{s}$ : Soil respiration; LST: Land surface temperature; NDVI: Normalized difference vegetation index; EVI: Enhanced vegetation index; LAI: Leaf area index; $R^{2}$ : Coefficient of determination; RMSE: Root-mean-square error; $r$ : Correlation coefficient; ChinaFLUX: China Flux Observation and Research Network; NEE: Net ecosystem carbon flux; $R_{g}$ : Solar radiation; $T_{a}$ : Air temperature; $T_{s}$ : Soil temperature; $S W C$ : Soil water content; P: Precipitation; VPD: Vapor pressure deficit; LSWI: Land surface water index.
\end{abstract}

\section{Acknowledgements}

All scientists and technicians maintaining the flux site management, data collection and long-term observations are greatly appreciated. The eddy covariance data and meteorological data are acquired from the Coordinated Observation and Synthesis in Arid and Semi-arid China (COSAS), a part of ChinaFLUX. We are also grateful to the Distributed Active Archive Center of the Oak Ridge National Laboratory, and the Earth Observing System Data for making these MODIS products available.

\section{Authors' contributions}

PY conceived the research; XT and ZD contributed to data analysis and wrote the manuscript; $Y Z$ and $H L$ provided data support; $L Y$ and $M M$ improved the manuscript. All authors read and approved the final manuscript.

\section{Funding}

The study was jointly supported by the National Natural Science Foundation of China (Grant Nos. 41830648, 41401221), the State Cultivation Base of Eco-agriculture for Southwest Mountainous Land, Southwest University China (Grant No. 5330200076) and Chongqing Basic and Frontier Research Program (Grant No. cstc2018jcyjAX0056).

Availability of data and materials

The data used in this article are available upon request.

\section{Competing interests}

The authors declare that they have no competing interests.

\section{Author details}

1 State Cultivation Base of Eco-agriculture for Southwest Mountainous Land, Southwest University, Chongqing 400715, China. ${ }^{2}$ Chongqing Jinfo Mountain Field Scientific Observation and Research Station for Karst Ecosystem (Southwest University), Ministry of Education, Chongqing 400715, China. ${ }^{3}$ International Institute for Earth System Science, Nanjing University, Nanjing 210023, China. ${ }^{4}$ Nanjing Institute of Geography and Limnology, Chinese Academy of Sciences, Nanjing 210008, China.

Received: 30 December 2019 Accepted: 17 April 2020

Published online: 24 April 2020

\section{References}

1. Ballantyne AP, Andres R, Houghton R, Stocker BD, Wanninkhof R, Anderegg W, Cooper LA, DeGrandpre M, Tans PP, Miller JB, Alden C, White JWC. Audit of the global carbon budget: estimate errors and their impact on uptake uncertainty. Biogeosciences. 2015;12:2565-84. 
2. Green JK, Seneviratne SI, Berg AM, Findell KL, Hagemann S, Lawrence DM, Gentine P. Large influence of soil moisture on long-term terrestrial carbon uptake. Nature. 2019;565:476-9.

3. Running SW, Nemani RR, Heinsch FA, Zhao M, Reeves M, Hashimoto $\mathrm{H}$. A continuous satellite-derived measure of global terrestrial primary production. Bioscience. 2004;54:547-60.

4. Wu C, Chen JM, Huang N. Predicting gross primary production from the enhanced vegetation index and photosynthetically active radiation: evaluation and calibration. Remote Sens Environ. 2011;115:3424-35.

5. Zhang L, Guo H, Jia G, Wylie B, Gilmanov T, Howard D, Ji L, Xiao J, Li J, Yuan W, Zhao T, Chen S, Zhou G, Kato T. Net ecosystem productivity of temperate grasslands in northern China: an upscaling study. Agric For Meteorol. 2014;184:71-81

6. Zhao M, Heinsch FA, Nemani RR, Running SW. Improvements of the MODIS terrestrial gross and net primary production global data set. Remote Sens Environ. 2005;95:164-76.

7. Chapin FS, Woodwell GM, Randerson JT, Rastetter EB, Lovett GM, Baldocchi DD, Clark DA, Harmon ME, Schimel DS, Valentini R, Wirth C, Aber JD, Cole JJ, Goulden ML, Harden JW, Heimann M, Howarth RW, Matson PA, McGuire AD, Melillo JM, Mooney HA, Neff JC, Houghton RA, Pace ML, Ryan MG, Running SW, Sala OE, Schlesinger WH, Schulze ED. Reconciling carbon-cycle concepts, terminology, and methods. Ecosystems. 2006;9(7):1041-50.

8. Schimel DS, House Jl, Hibbard KA, Bousquet P, Ciais P, Peylin P, Braswell BH, Apps MJ, Baker D, Bondeau A, Canadell J, Churkina G, Cramer W, Denning AS, Field CB, Friedlingstein P, Goodale C, Heimann M, Houghton RA, Melillo JM, Moore B, Murdiyarso D, Noble I, Pacala SW, Prentice IC, Raupach MR, Rayner PJ, Scholes RJ, Steffen WL, Wirth C. Recent patterns and mechanisms of carbon exchange by terrestrial ecosystems. Nature. 2001;414(6860):169.

9. Messerschmidt J, Parazoo N, Wunch D, Deutscher NM, Roehl C, Warneke T, Wennberg PO. Evaluation of seasonal atmosphere-biosphere exchange estimations with TCCON measurements. Atmos Chem Phys. 2013;13(10):5103-15.

10. Milyukova IM, Kolle O, Varlagin AV, Vygodskaya NN, Schulze ED, Lloyd J. Carbon balance of a southern taiga spruce stand in European Russia. Tellus Ser B Chem Phys Meteorol. 2002;54(5):429-42.

11. Byrne $B$, Wunch $D$, Jones DBA, Strong $K$, Deng $F$, Baker I, Köhler P, Frankenberg C, Joiner J, Arora VK, Badawy B, Harper AB, Warneke T, Petri C, Kivi R, Roehl CM. Evaluating GPP and respiration estimates over northern midlatitude ecosystems using solar-induced fluorescence and atmospheric $\mathrm{CO}_{2}$ measurements. J Geophys Res Biogeosci. 2018;123:2976-97.

12. Peylin P, Law RM, Gurney KR, Chevallier F, Jacobson AR, Maki T, Niwa Y, Patra PK, Peters W, Rayner PJ, Rödenbeck C, Van Der Laan-Luijkx IT, Zhang $X$. Global atmospheric carbon budget: results from an ensemble of atmospheric $\mathrm{CO}_{2}$ inversions. Biogeosciences. 2013;10:6699-720.

13. Tian H. Regional carbon dynamics in monsoon Asia and its implications for the global carbon cycle. Glob Planet Change. 2003;37:201-17.

14. Tang X, Li H, Ma M, Yao L, Peichl M, Arain A, Xu X, Goulden M. How do disturbances and climate effects on carbon and water fluxes differ between multi-aged and even-aged coniferous forests? Sci Total Environ. 2017;599:1583-97.

15. Wohlfahrt G, Anderson-Dunn M, Bahn M, Balzarolo M, Berninger F, Campbell C, Carrara A, Cescatti A, Christensen T, Dore S, Eugster W, Friborg T, Furger M, Gianelle D, Gimeno C, Hargreaves K, Hari P, Haslwanter A, Johansson T, Marcolla B, Milford C, Nagy Z, Nemitz E, Rogiers N, Sanz MJ, Siegwolf RTW, Susiluoto S, Sutton M, Tuba Z, Ugolini F, Valentini R, Zorer R, Cernusca A. Biotic, abiotic, and management controls on the net ecosystem $\mathrm{CO}_{2}$ exchange of European mountain grassland ecosystems. Ecosystems. 2008;11:1338-51.

16. Zheng C, Tang X, Gu Q, Wang T, Wei J, Song L, Ma M. Climatic anomaly and its impact on vegetation phenology, carbon sequestration and water-use efficiency at a humid temperate forest. J Hydrol. 2018;565:150-9.

17. Ai J, Jia G, Epstein HE, Wang H, Zhang A, Hu Y. MODIS-based estimates of global terrestrial ecosystem respiration. J Geophys Res Biogeosci. 2018;123:326-52.

18. Zhang Q, Lei HM, Yang DW. Seasonal variations in soil respiration, heterotrophic respiration and autotrophic respiration of a wheat and maize rotation cropland in the North China Plain. Agric For Meteorol. 2013;180:34-43.
19. Hinko-najera N, Fest B, Livesley SJ, Arndt SK. Agricultural and Forest Meteorology Reduced throughfall decreases autotrophic respiration, but not heterotrophic respiration in a dry temperate broadleaved evergreen forest. Agric For Meteorol. 2015;200:66-77.

20. Reichstein $M$, Falge E, Baldocchi D, Papale D, Aubinet M, Berbigier P, Bernhofer C, Buchmann N, Gilmanov T, Granier A, Grünwald T, Havránková K, Ilvesniemi H, Janous D, Knohl A, Laurila T, Lohila A, Loustau D, Matteucc G, Meyers T, Miglietta F, Ourcival JM, Pumpanen J, Rambal S, Rotenberg E, Sanz M, Tenhunen J, Seufert G, Vaccari F, Vesala T, Yakir D, Valentini R. On the separation of net ecosystem exchange into assimilation and ecosystem respiration: review and improved algorithm. Glob Change Biol. 2005;11:1424-39.

21. Lasslop G, Reichstein M, Papale D, Richardson A, Arneth A, Barr A, Stoy $P$, Wohlfahrt G. Separation of net ecosystem exchange into assimilation and respiration using a light response curve approach: critical issues and global evaluation. Glob Change Biol. 2010;16:187-208.

22. Gu Q, Wei J, Luo S, Ma M, Tang X. Potential and environmental control of carbon sequestration in major ecosystems across arid and semi-arid regions in China. Sci Total Environ. 2018;645:796-805.

23. Tang X, Wang Z, Liu D, Song K, Jia M, Dong Z, Munger JW, Hollinger DY, Bolstad PV, Goldstein AH, Desai AR, Dragoni D, Liu X. Estimating the net ecosystem exchange for the major forests in the northern United States by integrating MODIS and AmeriFlux data. Agric For Meteorol. 2012;156:75-84.

24. Xiao J, Zhuang Q, Baldocchi DD, Law BE, Richardson AD, Chen J, Oren R, Starr G, Noormets A, Ma S, Verma SB, Wharton S, Wofsy SC, Bolstad PV, Burns SP, Cook DR, Curtis PS, Drake BG, Falk M, Fischer ML, Foster DR, Gu L, Hadley JL, Hollinger DY, Katul GG, Litvak M, Martin TA, Matamala R, McNulty S, Meyers TP, Monson RK, Munger JW, Oechel WC, Paw UKT, Schmid HP, Scott RL, Sun G, Suyker AE, Torn MS. Estimation of net ecosystem carbon exchange for the conterminous United States by combining MODIS and AmeriFlux data. Agric For Meteorol. 2008;148:1827-47.

25. Huang N, He JS, Niu Z. Estimating the spatial pattern of soil respiration in Tibetan alpine grasslands using Landsat TM images and MODIS data. Ecol Indic. 2013;26:117-25.

26. Huang N, Gu L, Niu Z. Estimating soil respiration using spatial data products: a case study in a deciduous broadleaf forest in the Midwest USA. J Geophys Res. 2014;119:6393-408.

27. Wu C, Gaumont-Guay D, Andrew BlackT, Jassal RS, Xu S, Chen JM, Gonsamo A. Soil respiration mapped by exclusively use of MODIS data for forest landscapes of Saskatchewan, Canada. ISPRS J Photogramm Remote Sens. 2014:94:80-90.

28. Berryman $\mathrm{E}$, Vanderhoof MK, Bradford JB, et al. Estimating soil respiration in a subalpine landscape using point, terrain, climate and greenness data. J Geophys Res. 2018;123(10):3231-49.

29. Jägermeyr J, Gerten D, Lucht W, Hostert P, Migliavacca M, Nemani R. A high-resolution approach to estimating ecosystem respiration at continental scales using operational satellite data. Glob Change Biol. 2014;20(4):1191-210.

30. Ge R, He HL, Ren XL, Zhang L, Li P, Zeng N, Yu GR, Zhang LY, Yu SR, Zhang FW, Li HQ, Shi PL, Chen SP, Wang YF, Xin XP, Ma YM, Ma MG, Zhang Y, Du MY. A satellite-based model for simulating ecosystem respiration in the Tibetan and Inner Mongolian grasslands. Remote Sens. 2018;10(1):149.

31. Gao Y, Yu G, Li S, et al. A remote sensing model to estimate ecosystem respiration in Northern China and the Tibetan Plateau. Ecol Model. 2015;304:34-43.

32. Kang L, Han X, Zhang Z, Sun OJ. Grassland ecosystems in China: review of current knowledge and research advancement. Philos Trans R Soc B Biol Sci. 2007;362:997-1008

33. Wei J, Chen Y, Gu Q, Jiang C, Ma M, Song L, Tang X. Potential of the remotely-derived products in monitoring ecosystem water use efficiency across grasslands in Northern China. Int J Remote Sens. 2019;40:6203-23.

34. Schuman $G$, Janzen $H$, Herrick J. Soil carbon dynamics and potential carbon sequestration by rangelands. Environ Pollut. 2002;116(3):391-6.

35. Zhang $L$, Zhou G, Ji Y, Bai Y. Spatiotemporal dynamic simulation of grassland carbon storage in China. Sci China Earth Sci. 2016;59(10):1946-58.

36. Chen Y, Gu H, Wang M, Gu Q, Ding Z, Ma M, Liu R, Tang X. Contrasting performance of the remotely-derived GPP products over different climate zones across China. Remote Sens. 2019;11(16):1855.

37. Hua T, Wang $X$, Zhang C, Lang L, Li H. Responses of vegetation activity to drought in northern China. Land Degrad Dev. 2017;28(7):1913-21. 
38. Gilmanov TG, Svejcar TJ, Johnson DA, Angell RF, Saliendra NZ, Wylie BK. Long-term dynamics of production, respiration, and net $\mathrm{CO}_{2}$ exchange in two sagebrush-steppe ecosystems. Rangel Ecol Manag. 2006;59:585-99.

39. Mauder M, Foken T, Clement R, Elbers JA, Eugster W, Grünwald T, Heusinkveld B, Kolle O. Quality control of CarboEurope flux data-Part 2: inter-comparison of eddy-covariance software. Biogeosciences. 2008:5:451-62.

40. Wutzler T, Lucas-Moffat A, Migliavacca M, Knauer J, Sickel K, Šigut L, Menzer O, Reichstein M. Basic and extensible post-processing of eddy covariance flux data with REddyProc. Biogeosciences. 2018;15:5015-30.

41. Gilmanov TG, Johnson DA, Saliendra NZ. Growing season $\mathrm{CO}_{2}$ fluxes in a sagebrush-steppe ecosystem in Idaho: bowen ratio/energy balance measurements and modeling. Basic Appl Ecol. 2003;4:167-83.

42. Hibbard KA, Law BE, Reichstein M, Sulzman J. An analysis of soil respiration across northern hemisphere temperate ecosystems. Biogeochemistry. 2005;73(1):29-70.

43. Lioubimtseva E, Henebry GM. Climate and environmental change in arid Central Asia: Impacts, vulnerability, and adaptations. J Arid Environ. 2009;73(11):963-77.

44. Ahlström A, Raupach MR, Schurgers G, et al. The dominant role of semiarid ecosystems in the trend and variability of the land CO2 sink. Science. 2015;348(6237):895-99.

45. Poulter B, Frank D, Ciais P, Myneni RB, Andela N, Bi J, Broquet G, Canadell JG, Chevallier F, Liu Y, Running SW, Sitch S, Van der Werf GR. Contribution of semi-arid ecosystems to interannual variability of the global carbon cycle. Nature. 2014;509:600-3.

46. Soussana J-F, Loiseau P, Vuichard N, Ceschia E, Balesdent J, Chevallier T, Arrouays D. Carbon cycling and sequestration opportunities in temperate grasslands. Soil Use Manag. 2004;20:219-30.

47. Baldocchi D. Measuring fluxes of trace gases and energy between ecosystems and the atmosphere- - the state and future of the eddy covariance method. Glob Change Biol. 2014;20:3600-9.

48. Olofsson P, Lagergren F, Lindroth A, Lindström J, Klemedtsson L, Kutsch W, Eklundh $L$. Towards operational remote sensing of forest carbon balance across Northern Europe. Biogeosciences. 2008;5:817-32.

49. Reichstein M, Rey A, Freibauer A, Tenhunen J, Valentini R, Banza J, Casals P, Cheng Y, Grünzweig JM, Irvine J, Joffre R, Law BE, Loustau D, Miglietta F, Oechel W, Ourcival J-M, Pereira JS, Peressotti A, Ponti F, Qi Y, Rambal S, Rayment M, Romanya J, Rossi F, Tedeschi V, Tirone G, Xu M, Yakir D. Modeling temporal and large-scale spatial variability of soil respiration from soil water availability, temperature and vegetation productivity indices. Glob Biogeochem Cycles. 2003;17:4.

50. Anderson MC, Norman JM, Kustas WP, Houborg R, Starks PJ, Agam N. A thermal-based remote sensing technique for routine mapping of landsurface carbon, water and energy fluxes from field to regional scales. Remote Sens Environ. 2008;112:4227-41.

51. Hu Z, Yu G, Fan J, Zhong H, Wang S, Li S. Precipitation-use efficiency along a 4500-km grassland transect. Global Ecol Biogeogr. 2010;19(6):842-51.
52. Moyano FE, Manzoni S, Chenu C. Responses of soil heterotrophic respiration to moisture availability: an exploration of processes and models. Soil Biol Biochem. 2013;59:72-85.

53. Yan Z, Bond-Lamberty B, Todd-Brown KE, Bailey VL, Li S, Liu C, Liu C. A moisture function of soil heterotrophic respiration that incorporates microscale processes. Nat Commun. 2018;9:2562.

54. Chandrasekar K, Sesha Sai MVR, Roy PS, Dwevedi RS. Land Surface Water Index (LSWI) response to rainfall and NDVI using the MODIS vegetation index product. Int J Remote Sens. 2010;31:3987-4005.

55. Al-Yaari A, Wigneron JP, Ducharne A, Kerr Y, de Rosnay P, de Jeu R, Govind A, Al Bitar A, Albergel C, Muñoz-Sabater J, Richaume P, Mialon A. Globalscale evaluation of two satellite-based passive microwave soil moisture datasets (SMOS and AMSR-E) with respect to Land Data Assimilation System estimates. Remote Sens Environ. 2014;149:181-95.

56. Dong G, Guo J, Chen J, Sun G, Gao S, Hu L, Wang Y. Effects of spring drought on carbon sequestration, evapotranspiration and water use efficiency in the songnen meadow steppe in northeast China. Ecohydrology. 2011:4(2):211-24.

57. Chen S, Chen J, Lin G, Zhang W, Miao H, Wei L, Huang J, Han X. Energy balance and partition in Inner Mongolia steppe ecosystems with different land use types. Agric For Meteorol. 2009;149:1800-9.

58. Lian J, Huang M. Comparison of three remote sensing based models to estimate evapotranspiration in an oasis-desert region. Agric Water Manag. 2016;165:153-62.

59. Shao P, Zeng X, Sakaguchi K, Monson RK, Zeng X. Terrestrial carbon cycle: climate relations in eight CMIP5 earth system models. J Clim. 2013;26(22):8744-64.

60. Kato T, Tang Y, Gu S, Hirota M, Du M, Li Y, Zhao X. Temperature and biomass influences on interannual changes in $\mathrm{CO}_{2}$ exchange in an alpine meadow on the Qinghai-Tibetan Plateau. Glob Change Biol. 2006;12(7):1285-98.

61. Liu SM, Xu ZW, Wang WZ, Jia ZZ, Zhu MJ, Bai J, Wang JM. A comparison of eddy-covariance and large aperture scintillometer measurements with respect to the energy balance closure problem. Hydrol Earth Syst Sci. 2011;15:1291-306.

62. Hu Z, Yu G, Fu Y, Sun X, Li Y, Shi P, Wang Y, Zheng Z. Effects of vegetation control on ecosystem water use efficiency within and among four grassland ecosystems in China. Glob Change Biol. 2008;14(7):1609-19.

63. Wang Z, Xiao X, Yan X. Modeling gross primary production of maize cropland and degraded grassland in northeastern China. Agric For Meteorol. 2010;150(9):1160-7.

64. Shang L, Zhang Y, Lü S, Wang S. Energy exchange of an alpine grassland on the eastern Qinghai-Tibetan Plateau. Sci Bull. 2015;60(4):435-46.

\section{Publisher's Note}

Springer Nature remains neutral with regard to jurisdictional claims in published maps and institutional affiliations.

\footnotetext{
Ready to submit your research? Choose BMC and benefit from:

- fast, convenient online submission

- thorough peer review by experienced researchers in your field

- rapid publication on acceptance

- support for research data, including large and complex data types

- gold Open Access which fosters wider collaboration and increased citations

- maximum visibility for your research: over 100M website views per year
}

At $\mathrm{BMC}$, research is always in progress.

Learn more biomedcentral.com/submissions 